\title{
THE ABILITY OF MATHEMATICAL COMMUNICATION OF JUNIOR HIGH SCHOOL STUDENTS IN SOLVING OPEN-ENDED PROBLEMS GRAPHICS FUNCTION
}

\author{
Bella Anggraini Novitasari \\ Pendidikan Matematika, Fakultas Matematika dan Ilmu Pengetahuan Alam, Universitas Negeri Surabaya \\ Email : bellanovitasari16030174030@mhs.unesa.ac.id \\ Abdul Haris Rosyidi \\ Pendidikan Matematika, Fakultas Matematika dan Ilmu Pengetahuan Alam, Universitas Negeri Surabaya \\ Email : $\underline{\text { abdulharis@unesa.ac.id }}$
}

\begin{abstract}
The ability of mathematical communication is the skill to communicate mathematics that is learned and the skill of using mathematics as a communication tool (mathematical language). Mathematical communication skills are very necessary in learning. Without mathematical communication skills, a person will not be able to deliver statements according to their desire. This qualitative descriptive study aims to describe the level of mathematical communication ability of junior high school students in solving open ended problems with the topic of functional graphs. The method of collecting data through written tests and interviews. Written tests were given to 1158 th grade students of junior high schools in Surabaya, followed by interviews of one student at each level of mathematical communication ability. The results showed 51 people (44\%) were at fourth level, 27 people (24\%) at third level, 23 people (20\%) at second level, and 14 people (12\%) at first level. Students at fourth level and third level are equally able to use mathematical language that was accurate and effective, and appropriate in providing the strategies. But it was different in giving the arguments. Students at second level can not provide logical arguments, the mathematical language used was less effective and accurate, and the strategies used were precise but incomplete. Students at first level did not provide the right strategies because the lack of information which contained in the story, did not provide responses more to the stories they have been written, and did not demonstrate the ability to use mathematical language that was accurate and effective.
\end{abstract}

Keyword : ability of mathematical communication, open ended problem, graph of function

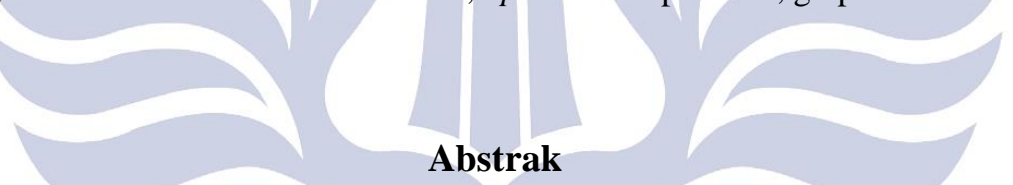

Kemampuan komunikasi matematika adalah keterampilan mengomunikasikan matematika yang dipelajari dan keterampilan menggunakan matematika sebagai alat komunikasi (bahasa matematika). Kemampuan komunikasi matematika sangat diperlukan dalam pembelajaran. Tanpa kemampuan komunikasi matematika, seseorang tidak akan mampu menyampaikan pernyataan sesuai dengan keinginannya. Penelitian deskriptif kualitatif ini bertujuan untuk mendeskripsikan level kemampuan komunikasi matematika siswa SMP dalam menyelesaikan masalah open ended topik grafik fungsi. Metode pengumpulan data melalui tes tertulis dan wawancara. Tes tulis diberikan kepada 115 siswa kelas 8 SMP negeri di Surabaya, dilanjutkan dengan wawancara pada satu siswa di setiap level kemampuan komunikasi matematis. Hasil penelitian menunjukkan, 51 orang (44\%) ada di level 4, 27 orang (24\%) di level 3, 23 orang (20\%) di level 2, dan 14 orang (12\%) di level 1. Siswa pada level 4 dan 3 sama-sama mampu menggunakan bahasa matematika yang akurat dan efektif, dan tepat dalam memberikan strategi. Tetapi berbeda dalam memberikan argumen. Siswa pada level 2 tidak dapat memberikan argumen yang logis, bahasa matematika yang digunakan kurang efektif dan akurat, serta strategi yang digunakan tepat namun tidak lengkap. Siswa pada level 1 tidak memberikan strategi yang tepat karena sedikitnya informasi yang tercantum pada ceritanya, tidak memberikan respon lebih lanjut terhadap cerita yang ditulisnya, serta tidak menunjukkan kemampuan dalam menggunakan bahasa matematika yang akurat dan efektif.

Kata kunci : Kemampuan komunikasi matematika, masalah open ended, grafik fungsi 


\section{INTRODUCTION}

Mathematical communication skill is an essential to enabling students to understand about the proceses, discussions, and decisions that are made (Viseu \& Oliveira, 2012). The ability of mathematical communication is skill to guide students to determine the ideas in various ways (Utami, 2015). Mathematical communication skill is the ability to presents the mathematics ideas orally, in writing, pictures, graphics, and others (NCTM, 2000). NCTM (2000) also mentions that students mathematical communication skill include: (1) the ability to express mathematical ideas in writing or verbally, show, and describe them visually; (2) the ability to understand, interpret, and evaluate mathematical ideas presented in written, oral, or visual forms; and (3) the ability to use mathematical vocabulary, symbols, and structure to represent the ideas, describe relationships, and model situations.

Mathematical communication skills are very necessary in learning. Without mathematical communication skills, a person will not be able to deliver statements according to their desire. Baroody (in Nurhayati, 2019) states that there are two reasons why communication is needed in mathematics, that is: (1) mathematics is essentially a language by itself, mathematics is not only a tool for thinking to find the patterns, solve problems and draw conclusions, but also a tool for communicating a variety of ideas, clearly, precisely, and succinctly, and (2) mathematics teaching and learning are social activities, mathematics can be used as a social activity because it requires an interaction between pupil and pupil, and teacher and pupil. When students communicate their mathematical thinking and reasoning they become observers of themselves and make invisible mathematical solutions more clear and visible to themselves and to their peers (Pourdavood \& Wachira, 2015). Guerreiro (2008) also states that mathematical communication is a tool to building the mathematics knowledge. In addition, mathematical communication also helps teachers to know students' understanding of the material that being taught.

Assessment of student mathematical communication should become an integral aspect of mathematics assessment (Cai, dkk 1996). Ponte says (in Viseu \& Oliveira, 2012) that the one way of doing the assesment is to use challenging problem such as open ended problem. The model that has developed in assasment of student mathematical communication is the open ended task by Cai, Jakabcsin, dan Lane (1996). Kosyvas (2015) also revealed that open ended problems will challenge students to use flexible thinking, understand mathematics, improve reasoning abilities and encourage students ability to reason and communicate mathematically.

Middle school student is generally more complex and abstract in their thinking (NCTM, 2000). However, at this age they are often reluctant to do something that makes them stand out and are often hesitant in expressing ideas or opinions to others, even though expressing ideas or opinions is one aspect of mathematical communication skills. Considering the importance of mathematics communication skills in learning, junior high school students are the right objects to study related to mathematical communication skills.

There are three types of rubrics that are often used to assesment of students mathematical communication skill, that is Maine Holistic Rubric for Mathematics by the Maine Department of Education, Maryland Math Communication Rubric by the Maryland State Department of Education and QUASAR General Rubric by Lane ( Johnson, 2004). The three types of rubrics classify several mathematical communication skill into five levels, that is $4,3,2,1$, and 0 .

As student communicate their mathematics ideas they need good representations of images, graphs, diagrams and others (Sabirin, 2014). At an early age, students are required to understand graphical representations in various contexts (Lowrie, 2011). However, many studies have identified students' weaknesses in interpreting graphics, for example research by Mustain (2015) which stated that student cannot read graphs well and have difficulties in interpreting graphs and data. In addition, Chang and Linn's (2013) study documented students' inability to understand graphs even though graphs were simple.

\section{METHOD}

This descriptive qualitative research aims to describe the level of mathematical communication skills of students in solving open ended problems on the topic of graph functions. This study uses a communication skills test instrument in the form of open ended questions which is adapted from the QCAI instrument (QUASAR Cognitive Assessment Instrument) and interview guidelines. The data obtained in this study are the results of mathematical communication skills tests and results of interviews. The study was conducted at one of the State Junior High Schools in Surabaya. Students will be given a test of mathematical communication skills in the form of open ended problems. The results of student answers will be grouped into levels based on the modified communication skills rubric of three types of rubrics, including Maine Holistic Rubric for Mathematics, Maryland Math Communication Rubric, and QUASAR General Rubric. 
Subjects at the same level are considered equivalent, so the researcher chooses one subject at each level of mathematical communication ability based on the answers that show the most complete indicators at each level. Then conducted the interviews by selecting subjects with the aim to explore information that has not been revealed through written tests. The subjects total at the time of the interview is a maximum of five students, if there are categories of levels that are not met by the research subjects, the researchers use the existing levels. The interview guide in this study is a semi-structured interview made by the researcher.

Table 1. Rubric of Mathematical Communication Skill

\begin{tabular}{|c|c|c|}
\hline Level & Code & Criteria \\
\hline \multirow[t]{3}{*}{4} & K4-1 & $\begin{array}{l}\text { The argument given is strong, logical, } \\
\text { and complete. }\end{array}$ \\
\hline & $\mathrm{K} 4-2$ & $\begin{array}{l}\text { Using effective and accurate } \\
\text { mathematical language (terms, } \\
\text { symbols, signs, and / or } \\
\text { representations) to describe concepts }\end{array}$ \\
\hline & $\mathrm{K} 4-3$ & $\begin{array}{l}\text { Giving the right strategy with the right } \\
\text { answer. }\end{array}$ \\
\hline \multirow[t]{3}{*}{3} & K3-1 & $\begin{array}{l}\text { The argument given is logical but there } \\
\text { is still an error. }\end{array}$ \\
\hline & $\mathrm{K} 3-2$ & $\begin{array}{l}\text { Using effective and accurate } \\
\text { mathematical language (terms, } \\
\text { symbols, signs, and / or } \\
\text { representations) to describe concepts. }\end{array}$ \\
\hline & $\mathrm{K} 3-3$ & $\begin{array}{l}\text { Providing the right strategy with } \\
\text { incorrect answers because there are } \\
\text { errors (for example all concepts are } \\
\text { identified in the story but there are at } \\
\text { least three true concepts based on the } \\
\text { time when the speed occurred). }\end{array}$ \\
\hline \multirow[t]{3}{*}{2} & K2-1 & The argument given is not logical. \\
\hline & K2-2 & $\begin{array}{l}\text { Using mathematical language (terms, } \\
\text { symbols, signs and / or } \\
\text { representations) that are less effective } \\
\text { and accurate to describe concepts. }\end{array}$ \\
\hline & $\mathrm{K} 2-3$ & $\begin{array}{l}\text { Providing the right strategy but it is } \\
\text { incomplete, so the answers given are } \\
\text { also incomplete (for example there are } \\
\text { three of the four concepts identified but } \\
\text { only a few that correspond to the time } \\
\text { when the speed occurs). }\end{array}$ \\
\hline \multirow[t]{3}{*}{1} & $\mathrm{~K} 1-1$ & $\begin{array}{l}\text { It does not provide arguments but it is } \\
\text { still able to explain }\end{array}$ \\
\hline & $\mathrm{K} 1-2$ & $\begin{array}{l}\text { Using mathematical language (terms, } \\
\text { symbols, signs and / or representations) } \\
\text { that are not effective and accurate to } \\
\text { describe concepts. }\end{array}$ \\
\hline & $\mathrm{K} 1-3$ & $\begin{array}{l}\text { Providing strategies that are not } \\
\text { appropriate because of the lack of } \\
\text { information related to the problem } \\
\text { given (for example, only refers to the } \\
\text { time but not with the speed). }\end{array}$ \\
\hline
\end{tabular}

\begin{tabular}{|l|l|l|}
\hline 0 & K0-1 & Words do not reflect the problem. \\
\cline { 2 - 3 } & K0-2 & $\begin{array}{l}\text { Out off the topic, illegible, blank, or } \\
\text { not enough to be rated. }\end{array}$ \\
\cline { 2 - 3 } K0-3 & $\begin{array}{l}\text { It does not provide a strategy with the } \\
\text { answers only copy the information that } \\
\text { provided on the problem. }\end{array}$ \\
\hline
\end{tabular}

There are two data analyses in this research, namely data analysis of mathematical communication ability test results and analysis of interview results. Data analysis of mathematical communication ability test based on the mathematical communication skills rubric in table 1, which is a modification of Maine Holistic Rubric for Mathematics rubric, Maryland Math Communication Rubric, and QUASAR General Rubric created by Lane. Maine Holistic Rubric is used to measure students 'communication skills in showing their completion strategies, QUASAR General Rubric is used to measure students' ability to provide responses and arguments, and Maryland Math Communication Rubric is used to measure the grammar used by students in showing mathematical communication.

Interview data analysis was carried out through the stages of data reduction, data presentation, and drawing conclusions (Miles et al, 2014: 12). Those are the problems used in this study.

"During the day, Tony started walking to his grandmother's house. He arrived at his grandmother's house at $3 \mathrm{pm}$. The chart below shows Tony's speed in miles per hour along his journey

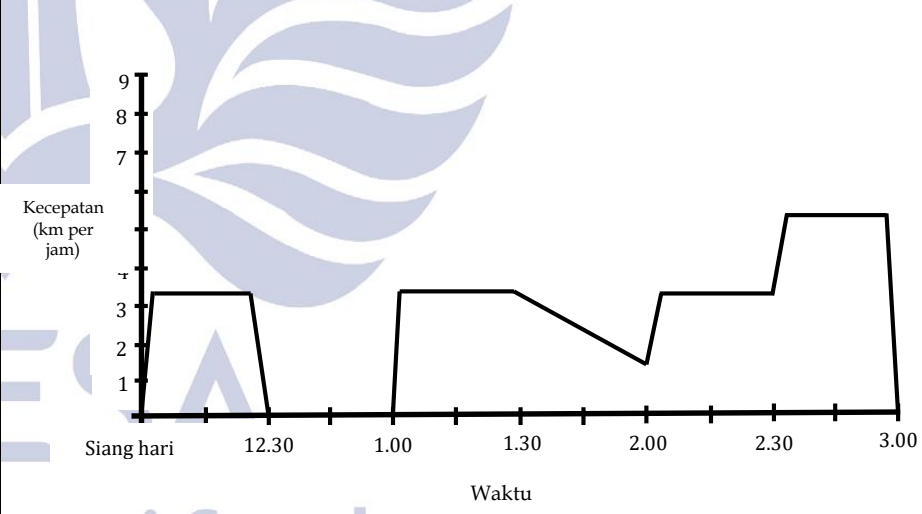

Write a story about Tony's journey based on the chart above and describe what did Tony do in the time lag!"

\section{RESULTS AND DISCUSSION}

\section{Results}

Based on the tests given to 115 8th grade of junior high school students, the following results were obtained:

Table 2. Mathematical Communication Ability Test Results

\begin{tabular}{|c|c|c|c|c|c|}
\hline Level & 4 & 3 & 2 & 1 & 0 \\
\hline Total & 51 & 27 & 23 & 14 & - \\
\hline Percent & $44 \%$ & $24 \%$ & $20 \%$ & $12 \%$ & $0 \%$ \\
\hline
\end{tabular}


From each level that appears, one subject is chosen for further analysis.

\section{Mathematical Communication Skills Level 4}

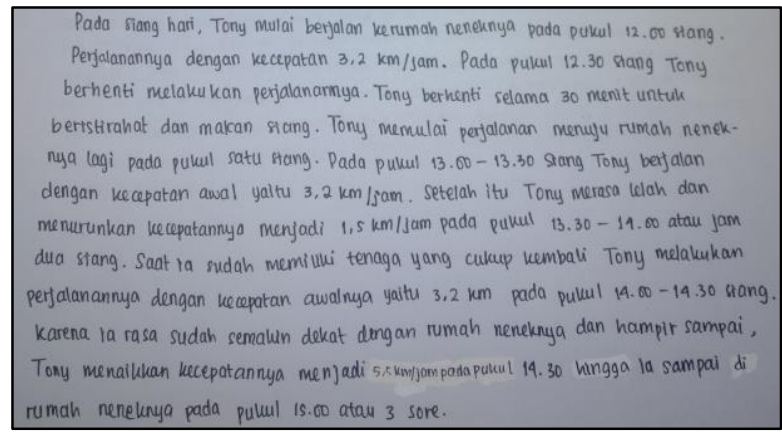

Figure 1. Level 4 Subject Test Results

The following interview excerpt shows the subject's arguments related to the story he made.

Researcher: Then how do you tell the blank part in the graph?

L4 Subject: I tell him, Tony is resting and having lunch Researcher: Why do you tell it like that?

L4 Subject: Because, the speed chart is $0 \mathrm{~km} / \mathrm{hour}$ meaning that Tony stops and I think, the suitable activity is rest. Because it is natural for someone to rest while on the way, the journey is also quite far and he walks

Based on the analysis of test results and interviews, subject at level 4 are able to explain that has been known and asked full questions. The subject also explained the story that has been written by showing what was listed in the story was based on the graphs presented in the questions and events that were told to see the conditions and the time. This ability shows that students provide strong, logical, and complete arguments (K4-1).

The following are excerpts of interviews with subjects related to their mathematical language.

Researcher: Can you indicate which important words represent the graphic images?

L4 Subject : Important words that represent the graphic image are like starting a journey, stopping, starting again, slowing down, returning to initial speed, increasing speed, and arriving at Grandma's house

In describing graphs, subjects choose the right words in describing events, so the subject is able to use accurate and effective mathematical language (K4-2), because the sentences arranged in the story are also clear and complete so that they are easily understood.

Related to the strategy used by the subject to create stories based on graphs can be seen in the following interview passage.
Researcher: Please explain how you made the story!

L4 Subject : First, I adjust the time with the speed sis, using a ruler so that the coordinates are right. Then I know that in the description of the problem it is told that Tony departed during the daytime, so that the first time setting is at 12:00 and then the chart rises means that Tony's speed went up too, then stabilized for 30 minutes because at 12:30 the speed was $0 \mathrm{~km} /$ hour. Because if the speed is $0 \mathrm{~km} / \mathrm{h}$, it means Tony stops, it will be until 1 o'clock, then the chart goes up again means Tony will start his journey again, then stabilize again with the same speed as before for 30 minutes too.

Then the graph is down, it means Tony's speed is also down, I told him Tony was tired. Then the chart at 2 o'clock rises again so the speed also rises to the same speed as before which is $3.2 \mathrm{~km} / \mathrm{h}$ until 2.30. Then the chart rises again at 2.30 to a speed of $5.5 \mathrm{~km} / \mathrm{h}$ and then is stable until 3 o'clock he arrives at his grandmother's house, because the speed is $0 \mathrm{~km} / \mathrm{hour}$

The strategy used by the subject is appropriate in designing, starting, and making the storyline based on graphs. The answers given also listed all the concepts of speed with time, where for a constant speed occurs at intervals of hours between 12.00-12.30, 1.00-1.30, 2.002.30 with speeds of $3.2 \mathrm{~km} / \mathrm{h}$ and intervals of hours between 2.30-3.00 with speeds $5.5 \mathrm{~km} / \mathrm{hr}$ on the journey made by Tony (K4-3).

\section{Mathematical Communication Skills Level 3}

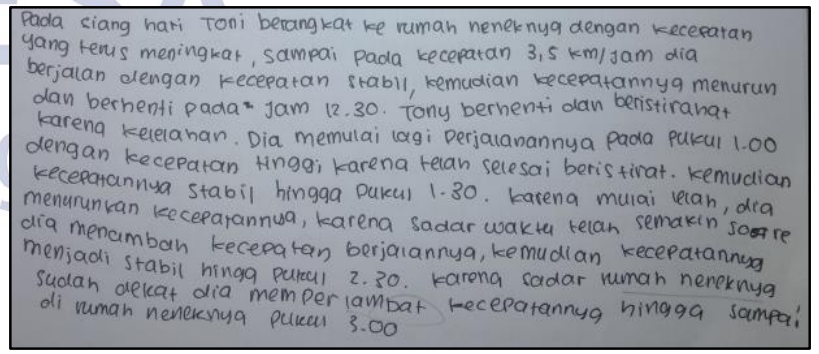

Figure 2. Level 3 Subject Test Results

The following interview excerpt shows the subject's arguments related to the story he made.

Researcher: How do you make sure Tony's speed increases or slows down?

L3 Subject: If the graph is leaning to the top right, that means the speed is going up, if 
leaning to the lower right that means slowing down

Researcher: How about a straight line?

L3 Subject: It means that the speed is stable sis, neither go up nor go down

Researcher: How many stable speeds in your story?

\section{L3 Subject : 3,5 km/hour}

Based on the analysis of the results of tests and interviews, subjects at level 3 are able to explain what is meant by the questions and those asked. The subject was able to explain what was written in the story with logical arguments but there were still errors in his understanding (K3-1), such as when responding when asked about Tony's constant speed, where the subject only mentioned $3.5 \mathrm{~km}$ / hr. The constant speed on Tony's trip should be $3.5 \mathrm{~km} /$ $\mathrm{hr}$ at $12.00-12.30,1.00-1.30,2.00-2.30$ and $5.5 \mathrm{~km} / \mathrm{h}$ at 2.30-3.00 hours.

The following are excerpts of interviews with subjects related to the mathematical language.

Researcher: Can you indicate which important words represent the graphic images?

L3 Subject : Increases, stabilizes, decreases, stops, high speeds, decreases speed, and slows down

In the story written, the subject describes each line on the graph using clear words. It shows that the subject uses an accurate mathematical language (K3-2), because the sentences arranged in the story are also clear and complete so that they are easy to understand.

Related to the strategy used by the subject to create stories based on graphs can be seen in the following interview passage.

Researcher: Please explain how you made the story!

L3 Subject: First, I determine the speed at each time. After that I made the story, beginning at 12 noon with a speed that continues to increase until stable at $3.5 \mathrm{~km} /$ hour. Then Tony stopped because at the 12:30 hour chart the speed was $0 \mathrm{~km} / \mathrm{hour}$. Then at 1 pm the speed increased sharply meaning Tony started his journey again until his speed was stable again. Then the graph down means the speed is also down, told I wrote it Tony felt tired. Then the speed rises again until stable at 2.30. then up again until near his grandmother's house he slowed down.

Because the subject understands the problem well, the strategies used are appropriate in designing, starting, and making the storyline based on graphs. Unfortunately, the answers given by the subject were not correct even though the strategy used was correct (K3-3), because the story presented was incomplete, there was still one concept that was not included, which was to increase the speed at 2.30 which then remained constant until 3.00. This is evidenced by the response of the subject who is able to show which lines are increasing, decreasing, and constant speed. The subject stated that the concept that was not written in the story happened because the subject lacked time to work.

\section{Mathematical Communication Skills Level 2}

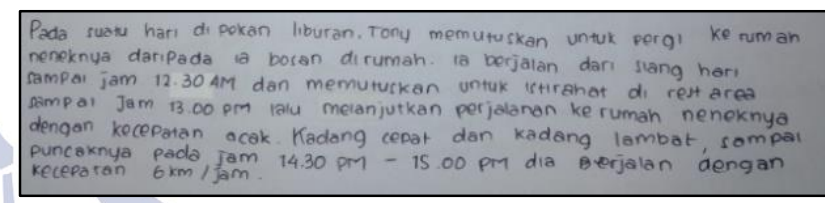

Figure 3. Level 2 Subject Test Results

The following interview excerpt shows the subject's arguments related to the story he made.

Researcher: Is your speed crossing your graphics right, 3 and $4 \mathrm{~km} /$ hour?

L2 Subject : Initially I wrote 3 and $4 \mathrm{~km} /$ hour, I was not careful, I think that the line was higher than the beginning

Based on the analysis of the results of tests and interviews, subjects at level 2 are able to explain what is meant by the questions and those asked, but it is still not fully familiar with the graphs presented in the questions, because in the story the constant speed that is written is incorrect. The subject states that the speed between 12.0012.30 and $1.00-1.30$ hours, $2.00-2.30$ is different, that is 3 $\mathrm{km} /$ hour and $4 \mathrm{~km} /$ hour, where there should be two kinds, namely at 12.00-12.30, 1.00-1.30, 2.00- 2.30 with the same speed and 2.30-3.00 with the same speed but it is greater, so the arguments given do not match the facts on the graph (K2-1).

The following are excerpts of interviews with subjects related to their mathematical language.

\section{Researcher: Can you show which graphic of the speed is random?}

L2 Subject: The one who goes up is from 1 o'clock, then the one that goes down is from half past 2 to 2, continues to go up at 2 to 2.30 , then goes up again until 3

Subjects use the word random speed to describe the graph, this word is used at intervals of 1.00 to 3.00. This shows that the subject does not explain in detail in the story but he still understands graphs, so the mathematical language used is less effective and accurate in describing concepts (K2-2). 
Related to the strategy used by the subject to create stories based on graphs can be seen in the following interview passage.

Researcher: Please explain how you made the story! L2 Subject: Leaving at 12 noon until 12:30 continues to stop because there are no lines in the chart. Then start again at 1 with a random speed, sometimes fast sometimes slow, until the highest speed is $6 \mathrm{~km} / \mathrm{h}$ from 14.30 to 3

The subject gives the right strategy in designing, starting, and making the storyline based on graphs. But the story written does not list all the concepts of speed, so the answers given are not complete (K2-3). Students only tell the charts between 12.00-12.30 and 12.30-13.00 hours. The charts in the following hours are only described at random speeds, sometimes fast, and sometimes slow, and don't tell Tony when he arrived at his grandmother's house. Students also did not tell about Tony's constant walking speed.

\section{Mathematical Communication Skills Level 1}

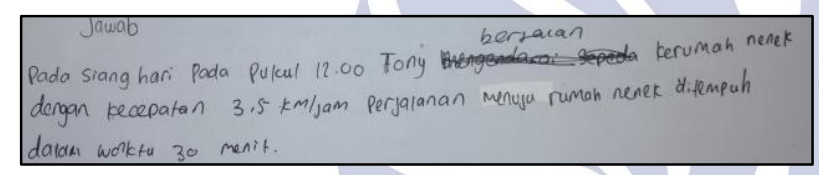

Figure 4. Level 1 Subject Test Results

The following interview excerpt shows the subject's arguments related to the story he made.

\section{Researcher: If you think the next graph is activity when you are at home, what about the time interval that has no lines? \\ L1 Subject: I don't understand about that sis, I only understand about it which has the line}

The subject gives no further response regarding his statement (K1-1), such as when asks about a picture without a line.

The following are excerpts of interviews with subjects related to their mathematical language.

\section{Researcher: Which of the words did you write that could represent a graphic image of the problem? \\ L1 Subject: The first sentence represents the graph line which is at 12.00 to $12: 30 \mathrm{pm}$}

The subject also did not show his ability to use mathematical language (K1-2).

Related to the strategy used by the subject to create stories based on graphs can be seen in the following interview passage.

\section{Researcher: Please explain how you made the story!}

L1 Subject: Tony walked to his grandmother's house from 12 noon for 30 minutes. Then at 1 to 3 it was Tony's activity at his grandmother's house

Based on the analysis of test and interview results, subject at level 1 does not understand the purpose of the questions and the graphs, so the strategies provided are not appropriate. The subject states that Tony's trip to his grandmother's house took 30 minutes, and concluded that the line at intervals of 1.00 to 3.00 is Tony's activity when he arrived at his grandmother's house. Students also do not tell Tony's activities between 12:30 and 13:00. This shows that the subject does not understand the graph well and does not utilize the additional information presented above the graph on the question sheet, so the strategy used is not appropriate because of the lack of information in the story (K1-3).

\section{Discussion}

Based on the analysis of the data above, students included in level 4, level 3, and level 2 have the same criteria in providing strategies. They both provided the right strategy, but not all of the answers given were correct. Correct answers are only presented by level 4 students, while level 3 provides incorrect answers because the stories presented are incomplete, as well as level 2 gives incorrect answers because it does not include all the speed concepts in the story. Level 4 and level 3 students also both provide logical arguments, even though the arguments given by level 3 students still have errors. Based on further interviews errors occur because students lack time in working on the problems so that what is done is incomplete. This is in line with Amalia (2017) that one of the causes of mistakes made by students is running out of time to solve problems.

In using mathematical language, level 4 and level 3 students both use effective and accurate mathematical language. Stories made by students related to their mathematical language (verbal representations) are still less varied, so that it seems monotonous in interpreting the same picture. This is in line with research by Hwang, et. Al (2007) that the score of students who use formula representation is better than students who use verbal and image representations.

\section{CLOSURE}

\section{Conclusion}

Based on the description above, from 115 students, students' mathematical communication skills are distributed as follows, 51 people (44\%) are at level 4, 27 people (24\%) at level 3, 23 people (20\%) at level 2, and 14 
people (12\%) at level 1. Students at levels 4 and 3 are both able to use mathematical language that is accurate and effective, and appropriate in providing strategies. But it is different in giving an argument. Students at level 2 cannot provide logical arguments, the mathematical language used is less effective and accurate, and the strategies used are precise but incomplete. Students with level 1 do not provide the right strategy because of the lack of information contained in the story, do not provide further response to the stories they write, and do not demonstrate their ability to use mathematical language that is accurate and effective.

\section{Suggestion}

Future studies should be considered related to variations in students' verbal representations used to create stories in interpreting the same picture. As in levels 3 and 4 there are different sentences when interpreting the same picture, that is the sentence "speed continues to increase" with a sentence without the words "continue to increase" but directly shows its speed.

\section{REFERENCES}

Amalia, Sofia Rizka. 2017. Analisis Kesalahan Berdasarkan Prosedur Newman Dalam Menyelesaikan Soal Cerita Ditinjau Dari Gaya Kognitif Mahasiswa. Aksioma. Vol. 8, No. 1

Cai, Jinfa, Jakabcsin, Mary S., dan Lane, Suzanne. 1996. Assessing Students' Mathematical Communication. School Science and Mathematics. Volume 96(5).

Chang HY, Linn MC. 2013. Scaffolding learning from molecular visualizations. J Res Sci Teach 50(7):858-886.

Guerreiro, A. 2008. Communication in mathematics teaching and learning: Practices in primary education.

Hwang, et al. 2007. Multiple Representatiom Skills and Creativity Effects on Mathematical Problem Solving using a Multimedia Whiteboard System. Educational Technology \& Society, Vol 10 No 2, pp. 191-212.

Johnson, 2004. Johnson Community College : Rubric Example. (Online), (http://www.jccc.net/home/depts/6111/site/assmnt /cogout/comwrite).
Kosyvas, Georgios. 2015. Levels of Arithmetic Reasoning in Solving an Open Ended Problem. International Journal of Mathematical Education in Science and Technology.

Lane, Suzanne. The Conceptual Framework for the Development of a Mathematics Performance Assessment Instrument. Educational Measurement: Issues and Practice, Summer 1993, 16-23.

Lowrie, Tom dan Diezmann Carmel. 2011. Solving graphics tasks: Gender differences in middleschool students. Learning and Instruction 21 109125.

Maryland State Department of Education, Sample activities, student responses and Maryland teachers' comments on a sample task: Mathematics Grade 8, February 1991.

Mustain, Iing. 2015. Kemampuan Membaca Dan Interpretasi Grafik Dan Data: Studi Kasus Pada Siswa Kelas 8 Smpn. Scientiae educatia vol. 5 no. 2.

National Council of Teacher of Mathematics. 2000. Prinsiples and Standarts for School Mathematics. Reston, Virginia: NCTM.

Nurhayati, dkk. 2019. Komunikasi Matematis Tulis Siwa Melalui Penerapan Student Center Learning. Jurnal Pendidikan:Teori, Penelitian, dan Pengembangan Volume: 4 Nomor: 7 Hal: 951-959

Pourdavood dan Wachira. 2015. Importance of Mathematical Communication and Discourse in Secondary Classroom. Global Journal of Science Frontier Research: F Mathematics and Decision Sciences.

Sabirin, Muhammad. 2014. Representasi Dalam Pembelajaran Matematika. JPM IAIN Antasari. Vol. 01 No. 2, 33-44.

Viseu, Floriano dan Oliveira, Inês Bernardo. 2012. Open ended Tasks in the Promotion of Classroom Communication in Mathematics. International Electronic Journal of Elementary Education, 4(2). 287-300

Utami, C. 2015. Pembelajaran Model Generatif dengan Strategi Group Investigation untuk Meningkatkan Kemampuan Komunikasi Matematis Siswa. Unnes Journal of Mathematics Education Research, 4(1), $18-25$. 